\title{
Pengaruh Kejenuhan Kerja (Burnout) Terhadap Kinerja Karyawan Bagian Operator Di PT PLN (Persero) Unit Pelaksana Pengendalian Pembangkit Jambi Unit Layanan Pusat Listrik Payo Selincah
}

\author{
Said Almaududi \\ Universitas Batanghari Jambi \\ Correspondence email: saidalmaududi@yahoo.com
}

\begin{abstract}
Excessive and prolonged work stress can cause depression and if not immediately addressed can cause employees to experience burnout syndrome, an emotional condition where an employee feels tired and bored both physically and mentally. On the other side it can be seen that the performance at PLN Persero Company has not been said to be optimal because it is unable to handle public complaints effectively and efficiently. The research aims to find out how the influence of burnout on the performance of the operator's employees in PLN Persero Company Jambi Power Plants Control Unit Payo Selincah Central of Electric Service Unit as well as how much influence the burnout on the performance of the operator employee employees at PLN Persero Company Jambi Power Plants Control Unit Payo Selincah Central of Electric Service Unit. The research method used is a descriptive quantitative method with burnout and the dependent variable is performance. The analytical tool used is simple linear regressionanalysis, correlationanalysis, coefficient of determination analysis and statistical test t analysis. The object of this research is the operator part of employees PLN Persero Company Jambi Power Plants Control Unit Payo Selincah Central of Electric Service Unit. Based on the results of simple linear regression analysis, showing the equation $Y=36,545+0,546$ with a correlation of 0,542 or 54,2\%. Determination value of 0,294 or 29,4\% which means that the influence of burnout on performance is $29,4 \%$, while $70,6 \%$ is influenced by other variables not examined in this study. T test value of 3,974 with a significance value of 0,00<0,05 which is greater than the table value of 2,02439. This research is to show that the level of burnout and the performance of the operator's employees in PLN Persero Company Jambi Power Plants Control Unit Payo Selincah Central of Electric Service Unit is high. And burnout also affects the performance of the operator's employees in the PLN Persero Company Jambi Power Plants Control Unit Payo Selincah Central of Electric Service Unit.
\end{abstract}

Keywords; Human resource; Burnout; Performance

\section{PENDAHULUAN}

Setiap karyawan memiliki dorongan dan kebutuhan pokok yang bersifat utama (fisik maupun psikis) serta bersifat sosial. Tanpa disadari semuanya menuntut pemuasan. Jika tidak terpenuhi maka dapat menimbulkan ketegangan. Apalagi untuk pekerja yang bekerja dibagian industri dan pelayanan. Ketegangan itupun dapat memberikan efek berupa stres kerja. Stress kerja merupakan bentuk tanggapan baik secara fisik maupun mental terhadap perubahan di lingkungan kerja yang dirasakan mengganggu dan mengakibatkan dirinya terancam. Stres kerja yang berkepanjangan dapat menimbulkan depresi dan jika tidak segera diatasi dan cenderung lama dapat membuat karyawan terkena sindrom burnout yaitu kondisi emosional dimana seseorang merasa lelah dan jenuh baik secara fisik maupun mental, sebagai akibat dari tuntutan pekerjaan yang meningkat.

PT PLN merupakan satu-satunya Badan Usaha Milik Negara yang bergerak dibidang penyediaan tenaga listrik bagi kepentingan umum yang kebutuhannya meningkat setiap tahunnya. Kebutuhan listrik Provinsi Jambi didapatkan dari sistem kelistrikan yang terinterkoneksi dari sumatera bagian utara hingga sumatera bagian selatan, di Jambi sendiri kelistrikan diproduksi oleh PT PLN PerseroUnit Pelaksana Pengendalian Pembangkit Jambi yang berada di Unit Layanan Pusat Listrik Payo Selincah. Seperti yang terlihat di beberapa media massa, begitubanyak keluhan masyarakat terhadap kinerja pegawai PT PLN. Banyak masyarakatyang mengeluh tentang pemadaman listrik yang dianggap masyarakat cenderungsemenamena. Kritikan masyarakat terhadap PLN harus jadi bahan introspeksi bagi seluruh pegawai PLN. Kutipan tersebut dapat terlihat bahwa kinerja PT PLN belum dikatakanmaksimal karena tidak mampu menangani keluhan masyarakat secara efektif danefisien. Oleh sebab itu, PT PLN merasa perlu meningkatkan kualitas fisik dan mental terkhusus para pegawai operasi. Karyawan merupakan aset yang penting dalam keberhasilan produksi. Karyawan bagian operasi merupakan ujung tombak penentu produksi. Perusahaan telah menetapkan standarisasi kerja yang sangat tinggi kepada karyawan operasi guna meningkatkan kualitas produksi listrik. Para karyawan dituntut memiliki kinerja yang baik serta etos kerja yang tinggi, melakukan pekerjaan dengan totalitas, bekerja sesuai prosedur operasi, disiplin yang tinggi dan dituntut memiliki 
konsentrasi yang tinggi yang diharapkan meningkatnya motivasi karyawan dalam mencapai target sesuai standar yang telah ditetapkan perusahaan. Di sisi lain, adanya beban kerja yang tinggi pada karyawan bagian operator yang bekerja secara shift menuntut mereka memiliki fisik yang prima, pekerjaan yang monoton dan berulang-ulang dan tidak variatif berdampak pada munculnya kelelahan kerja pada karyawan yang kemudian berimbas pada burnoutserta menurunnya kinerja para karyawan. Crosby (2012) mengatakan burnout juga bisa terjadi akibat kurangnya penghargaan positif atas kerja yang selama ini dikerjakan. Burnout disuatu perusahaan bisa diukur dari banyaknya pengunduran diri dan kurangnya kepuasan karyawan.

\section{Landasan Teori}

\section{Kejenuhan Kerja (Burnout)}

Menurut Setyawati dalam Widanti (2010), bahwa secara umum burnout merupakan keadaan yang dialami tenaga kerja yang dapat mengakibatkan penurunan vitalitas dan produktivitas kerja.Pines dan Aronson dalam Suharto (2007:53) mendefinisikan burnout sebagai berikut: A state of mind accomppanied by an arangement of symptoms that include a general malaise: emotional, Phsycal, mental fatigue; feeling of helplessness, and a lack of enthusiasm about work and even about life in general. Pengertian di atas diartikan bahwa burnout merupakan suatu keadaan pikiran yang disertai oleh susunan gejala yang meliputi: keletihan emosional, fisik dan mental, perasaan tidak berdaya, serta kurang antusiasme terhadap pekerjaan dan bahkan terhadap kehidupan pada umumnya.

Burnout menurut Freudenberger dalam Edi Suharto (2007: 53) menjelaskan bahwa gejala-gejala biasanya mencakup sikap sinis dan negatif, kekuatan dalam berpikir yang sering mengarah pada pikiran buntu yang tertutup pada perubahan atau inovasi. Orang yang mengalami burnout biasanya bersifat sinis dan memandang klien sebagai orang yang pantas mendapatkan masalah karena kesalahan mereka sendiri, yang pada gilirannya menurunkan kualitas pelayanan yang diberikan. Burnout dapat menghinggap di dalam diri manusia tidak memandang usia, jenis kelamin, pekerjaan, pendidikan dan semakin disadari sebagai sesuatu masalah serius yang dapat mempengaruhi kehidupan seseorang.

George (2005) dalam Efa (2011), menjelaskan tentang gejala-gejala burnout, yaitu:

a. Kelelahan fisik, yang ditunjukkan dengan adanya kekurangan energi, merasa kelelahan dalam kurun waktu yang panjang dan menunjukkan keluhan fisik seperti sakit kepala, mual, susah tidur, dan mengalami perubahan kelelahan makan yang diekspresikan dengan kurang bergairah dalam bekerja, lebih banyak melakukan kesalahan, merasa sakit padahal tidak terdapat kelainan fisik.

b. Kelelahan mental, yang ditunjukkan oleh adanya sikap sinis terhadap orang lain, bersikap negatif terhadap orang lain, cenderung merugikan diri sendiri, pekerjaan dan organisasi, umumnya diekspresikan dengan mudah curiga terhadap orang lain, menunjukkan sikap sinis terhadap orang lain, menunjukan sikap agresif baik dalam bentuk ucapan maupun perbuatan, menunjukkan sikap masa bodoh terhadap orang lain dan dengan sengaja menyakiti diri sendiri.

c. Kelelahan emosional, yang ditunjukkan oleh gejala-gejala seperti depresi, perasaan tidak berdaya, dan merasa terperangkap dalam pekerjaan yang 4 diekspresikan dengan sering merasa cemas dalam bekerja, mudah putus asa, merasa tersiksa dalam melaksanakan pekerjaan, mengalami kebosanan atau kejenuhan dalam bekerja.

d. Penghargaan diri yang rendah, ditandai oleh adanya penyimpulan bahwa dirinya tidak mampu menunaikan tugas dengan baik dimasa lalu dan beranggapan sama untuk masa depannya yang diekspresikan dengan merasa tidak pernah melakukan sesuatu yang bermanfaat, menganggap bahwa pekerjaan sudah tidak mempunyai arti bagi dirinya, menganggap bahwa dirinya tidak mempunyai masa depan di perusahaan.

\section{Kinerja}

Kinerja pegawai menjadi faktor yang paling berkaitan dengan kemajuansuatu organisasi, karena melalui kinerja pegawai lah maka sebuah perusahaan dapatterus berlanjut untuk beroperasi. Ketika kinerja pegawai mengalami penurunan yangsangat drastis maka bisa saja berimbas kepada kondisi perusahaan yang tentunyamengalami perubahan dari posisi yang menguntungkan menjadi rugi. Menurut Moeheriono 
(2009:60) kinerja atau performance merupakangambaran mengenai tingkat pencapaian pelaksanaan suatu program kegiatan atau kebijakan dalam mewujudkan sasaran, tujuan, visi, dan misi organisasi yangdituangkan melalui perencanaan strategis suatu organisasi. Kinerja dapat diketahuidan diukur jika individu atau sekelompok pegawai telah mempunyai kriteria ataustandar keberhasilan tolak ukur yang ditetapkan organisasi. Kaswan (2012:187) menyebutkan kinerja adalah hasil atau tingkat keberhasilan seseorang secara keseluruhan selama perode tertentu dalam melaksanakan tugas dibandingkan dengan bebagai kemungkinan, seperti standar hasil kerja, target atau sasaran atau kriteria yang telah ditentukan terlebih dahulu dan telah disepakati bersama. Ada 6 kriteria utama yang digunakan dalam menilai kinerja yaitu :

1) Kualitas, seberapa jauh atau baik proses atau hasil menjalankan aktivitas mendekati kesempurnaan ditinjau dari kesesuaian dengan cara ideal menjalankan suatu kegiatan atau memenuhi tujuan yang dikehendaki oleh aktivitas suatu usaha. Kualitas kerja erat kaitannya dengan pekerjaan diselesaikan dengan baik, ketelitian, memiliki keterampilan menyelesaikan pekerjaan serta keakuratan.

2) Kuantitas, Jumlah yang dihasilkan, dinyatakan dalam nilai, jumlah unit atau jumlah siklus kegiatan yang telah diselesaikan. Kuantitas meliputi ; beban kerja disesuaikan dengan kemampuan, dapat menyelesaikan pekerjaan dengan cepat serta menyelesaikan target dengan baik.

3) Ketepatan waktu, Seberapa jauh atau baik sebuah aktivitas diselesaikan, atau hasil yang diproduksi pada waktu yang paling awal yang dikehendaki dari sudut pandang koordinasi dengan output yang lain maupun memaksimumkan waktu yang ada untuk kegiatan-kegiatan lain. Ketepatan waktu berkaitan dengan menyelesaikan pekerjaan sesuai waktu serta dapat menyesuaikan pekerjaan sesuai dengan berat ringannya pekerjaan.

4) Efektivitas biaya, Seberapa jauh atau baik sumber daya organisasi misalnya manusia, moters, tekhnologi, bahan) dimaksimumkan dalam pengertian memperoleh keuntungan tertinggi atau pengurangan dalam kerugian dari masing-masing unit atau contoh penggunaan sumber daya. Efektivitas biaya meliputi : anggaran cukup untuk menyelesaikan pekerjaan serta dapat menekan biaya dalam bekerja.

5) Kebutuhan untuk supervisi. Seberapa jauh atau baik seorang karyawan dapat melaksanakan fungsi kerja tanpa harus meminta bantuan pengawas atau memerlukan intervensi pengawasan untuk mencegah hasil yang merugikan. Kebutuhan untuk supervisi meliputi ; menyelesaikan pekerjaan sesuai instruksi atasan, memiliki insiatif dalam bekerja, mengedepankan kehati-hatian dalam bekerja, selalu berusaha meningkatkan prestasi kerja serta mampu bekerja secara independen.

6) Dampak interpersonal, Seberapa jauh atau baik pegawai meningkatkan harga diri, itikad baik (goodwill) dan kerjasama antara sesama pegawai dan bawahan.

\section{Penelitian Terdahulu}

Penelitian yang dilakukan oleh Dzul Akbar Insani, Sri Lestari Ramadhani Nasution, Suci Erawati dan Rapael Ginting pada tahun 2018 yaitu Pengaruh Tingkat Kejenuhan terhadap Kinerja Perawat Wanita di Ruang Rawat Inap Rumah Sakit Umum Royal Prima Tahun 2018 menghasilkan kesimpulan bahwa terdapat hubungan yang secara statistik kejenuhan terhadap kinerja $(p=0,006)$. Dilihat dari nilai OR adalah 6,667 yang artinya perawat dengan tingkat kejenuhan yang teratasi baik akan meningkatkan kinerja sebesar 6,6 kali dibandingkan perawat dengan tingkat kejenuhan yang tidak teratasi atau buruk. Sedangkan penelitian yang dilakukan Savitri Suryandari pada tahun 2016yaitu Pengaruh Burnout,Self Esteem terhadap Kinerja menghasilkan kesimpulan bahwa terjadinya Burnout ( kejenuhan kerja ) serta Self Esteem ( harga diri ) yang negatif dapat menyebabkan terjadinya penurunan pada kinerja guru. Walaupun tidak semua guru bisa mengalaminya. Hal ini disebabkan burnout serta self esteem tidak secara sepenuhnya dapat mempengaruhi kinerja guru, tetapi tergantung pada kondisi guru itu sendiri. Burnout dan Self Esteem yang negatif tidak selalu terjadi pada setiap guru, karena adanya perbedaan didalam mempengaruhi kondisi fisik, emosi dan mental seorang guru. Adapun hal yang memiliki kontibusi yang besar terhadap timbulnya Burnout dan Self Esteem adalah adanya perasaan tidak bernilai, tidak dihargai, sehingga pekerjaannya tidak berarti. 


\section{METODE PENELITIAN}

Objek penelitian yang dilakukan adalah pengaruh kejenuhan kerja (burnout) terhadap kinerja karyawan bagian operator di PT PLN Persero Unit Pelaksana Pengendalian Pembangkit Jambi Unit Layanan Pusat Listrik Payo Selincah. Dalam hal ini data primer yang digunakan dalam penelitian ini adalah data jawaban responden yang diambil melalui observasi dan penyebaran kuisoner. Sedangkan data sekunder yang digunakan pada penelitian ini adalahliteratur atau buku-buku perpustakaan,dan dokumen penunjang yang dimiliki PT PLN Persero Unit Pelaksana Pengendalian Pembangkit Jambi Unit Layanan Pusat Listrik Payo Selincah yang berupa data karyawan, data realisasi produksi KWH dari rentang tahun 2013 sampai dengan 2017 dan pencarian bahan-bahan yang relevan melalui internet.

Metode yang digunakan dalam pengumpulan data untuk penelitian ini adalah dengan metode Library Research. Populasi dan sampel dalam penelitian ini adalahseluruh pegawai operator kantor PT PLN PerseroUnit Pelaksana Pengendalian Pembangkit Jambi Unit Layanan Pusat Listrik Payo Selincah yang berjumlah 40 orang karyawan bagian operator. Berdasarkan latar belakang masalah pokok dan hipotesis yang dikemukakan sebelumnya, maka metode analisis yang digunakan untuk pengujian dan pembuktian hipotesis adalah :

1. Analisis Deskriptif, yaitu analisis yang dilakukan untuk menilai karakteristik dari sebuah data yang dilaksanakan pada PT PLN Persero Unit Pelaksana Pengendalian Pembangkit Jambi Unit Layanan Pusat Listrik Payo Selincah.

2. Analisis Kuantitatif, mengumpulkan data-data dan menyatakan variabel-variabel yang menggambarkan presepsi para pegawai terhadap kejenuhan kerja terhadap kinerja mereka itu sendiri. Jumlah sampel yang digunakan oleh penulis sebanyak 40 orang. Yang pada akhirnya akan menjadi total skor dari pengisian kuesioner responden. Untuk pengisian kuesioner telah disediakan alternative jawaban dari 1-5 menggunakan skala likert.

Tabel 1

Skala Pengukuran Instrumen

\begin{tabular}{lc}
\hline Skala pengukuran instrument & Skor \\
\hline Sangat Tidak Setuju & 1 \\
Tidak Setuju & 2 \\
Tidak Tahu & 3 \\
Setuju & 4 \\
Sangat Setuju & 5 \\
\hline
\end{tabular}

Untuk menganalis tanggapan karyawan bagian operator mengenai Kejenuhan Kerja (Burnout) pada PT PLN Persero Unit Pelaksana Pengendalian Pembangkit Jambi Unit Layanan Pusat Listrik Payo Selincah menggunakan skala penelitian dalam menghitung item pertanyaan.Seperti yang dikemukakan Umar (2001 ; 225) bahwa perhitungan skor setiap komponen yang diteliti dengan mengalikan seluruh frekuensi data dengan nilai bobot.Untuk kepuasan tiap dimensi dapat dicari dengan menghitung interval sebagai berikut :

$\begin{array}{ll}\text { Skor terendah } & =\text { Bobot terendah } \times \text { jumlah sampel } \\ \text { Skor tertinggi } & =\text { bobot tertinggi } \times \text { jumlah sampel } \\ \text { Skor terendah } & =1 \times 40=40 \\ \text { Skor tertingi } & =5 \times 40=200\end{array}$

Sedangkan untuk mencari rentang skala yang digunakan rumus sebagai berikut :

Rentang Skala $(\mathrm{RS})=\frac{\mathrm{n}(\mathrm{m}-1)}{\mathrm{m}}$

Dimana: $\mathrm{n}=$ Jumlah sampel; $\mathrm{m}=$ Nilai alternative jawaban

$\mathrm{RS}=\frac{40(5-1)}{5}=32$ 
Sehingga interval kelasnya adalah:

$$
\begin{array}{ll}
40-72 & =\text { Sangat Tidak Setuju } \\
73-104 & =\text { Tidak Setuju } \\
105-136 & =\text { Tidak Tahu } \\
137-168 & =\text { Setuju } \\
169-200 & =\text { Sangat Setuju }
\end{array}
$$

\section{Alat Analisis \\ Regresi Linier Sederhana}

Untuk melihat mana pengaruh kejenuhan kerja (burnout) terhadap kinerja pegawai pada PT PLN Persero Unit Pelaksana Pengendalian Pembangkit Jambi Unit Layanan Pusat Listrik Payo Selincah digunakan rumus regresi linier sederhana yang diolah menggunakan alat bantu program SPSS 21. Menurut Sugiyono (2014:270) rumus regresi sederhana sebagai berikut :

$\mathrm{Y}=\mathrm{a}+\mathrm{bX}+\mathrm{e}$

Keterangan $: \mathrm{Y}=$ Kinerja; $\mathrm{b}=$ Koefesien Regresi; $\mathrm{a}=$ Konstanta; $\mathrm{X}=$ Kejenuhan Kerja/Burnout; $\mathrm{e}=$ Error

\section{Korelasi}

Menurut Kurniawan (2009:26) korelasi adalah hubungan atau keeratan antara 2 variabel, dimana terdiri dari 1 variabel independen (bebas) dan 1 variabel dependen (terikat) dan juga mengetahui arah hubungan. Adapun pedoman arti korelasi sebagai berikut :

Tabel 2

\begin{tabular}{ll}
\hline & Pedoman Korelasi \\
\hline $0,00-0,199$ & Sangat tidak erat \\
$0,20-0,399$ & Tidak erat \\
$0,40-0,599$ & Cukup erat \\
$0,60-0,799$ & Erat \\
$0,80-1,000$ & Sangat erat \\
\hline
\end{tabular}

\section{Koefisien Determinasi}

Menurut Supardi (2013:188) koefisien determinasi dilambangkan dengan $r^{2}$. Nilai ini menyatakan proporsi variasi keseluruhan dalam nilai dependen yang dapat diterangkan atau diakibatkan oleh hubungan linear dengan variabel independen, selain itu (sisanya) diterangkan oleh variabel yang lain (galat atau peubah lainnya). Nilai koefisien determinasi dinyatakan dalam kuadrat dari nilai koefisien korelasi $r^{2}$ x 100 $\%=\mathrm{n} \%$, memiliki makna bahwa nilai variabel dependen dapat diterangkan oleh variabel independen sebesar $\mathrm{n} \%$, sedangkan sisanya sebesar $(100-\mathrm{n}) \%$ diterangkan oleh galat (error) atau pengaruh variabel yang lain. Sedangkan untuk analisis korelasi dengan jumlah variabel dependen lebih dari 1 (ganda / majemuk) terdapat koefisien determinasi penyesuaian (adjustment) yang sangat sensitif dengan jumlah variabel. Biasanya untuk analisis korelasi majemuk / ganda yang sering dipakai adalah koefisien determinasi penyesuaian (koefisien determinasi sederhana tidak memperhatikan jumlah variabel independen). Rumus yang dipakai adalah :

$\mathrm{KD}=\mathrm{r}^{2} \times 100 \%$

Keterangan : $\mathrm{KD}=$ Koefisien determinasi $\mathrm{R}=$ Koefisien korelasi

\section{Uji Hipotesis}

\section{Uji $t$}

Uji t pada dasarnya menunjukkan seberapa jauh pengaruh satu variabel penjelas secara individual dalam menerangkan variasi variabel terikat. Menurut Sugiyono (2010:250) merumuskan uji t sebagai berikut: 
$t=\frac{r \sqrt{n-2}}{\sqrt{1-r^{2}}}$

Dimana $: \mathrm{t}=$ distribusi $\mathrm{t} ; \mathrm{n}=$ jumlah data; $\mathrm{r}=$ koefisien korelasi parsial; $\mathrm{r}^{2}=$ koefisien determinasi Hipotesis uji $\mathrm{t}$ :

$\mathrm{H}_{0}: \mathrm{b}_{1}=0$, apakah suatu variabel independen bukan merupakan penjelas yang signifikan terhadap variabel dependen.

$\mathrm{H}_{\mathrm{a}}: \mathrm{b}_{1} \neq 0$, variabel tersebut merupakan penjelas yang siginifikan terhadap variabel dependen.

Cara melakukan uji t adalah dengan cara sebagai berikut : (Kuncoro, 2009:239)

a. Quick look : Bila jumlah degree of freedom adalah 20 atau lebih, dan derajat kepercayaan sebesar 5\%, maka $\mathrm{H}_{0}$ yang menyatakan $\mathrm{b}_{1}=0$ dapat ditolak bila nilai t lebih besar dari 2 (dalam nilai absolut). Dengan kata lain, kita menerima hipotesis alternatif, yang menyatakan bahwa suatu variabel independen secara individual mempengaruhi variabel dependen.

b. Membandingkan nilai statistik $t_{\text {hitung }}$ dan nilai $t_{\text {tabel }}$, jika nilai statistik $t_{\text {hitung }}>t_{\text {tabel }}$ maka $\mathrm{H}_{\mathrm{o}}$ ditolak dan $\mathrm{H}_{\mathrm{a}}$ diterima, yang menyatakan bahwa suatu variabel independen secara individual mempengaruhi variabel dependen.

\section{HASIL DAN PEMBAHASAN}

Analisis Deskrptif terhadap Indikator Kejenuhan Kerja (burnout)

Tabel 3

Analisis Deskriptif Terhadap Indikator Burnout

\begin{tabular}{llrr}
\hline No Urut & Indikator & Skor & Keterangan \\
\hline 1 & Kelelahan Fisik & 147,00 & Setuju \\
2 & Kelelahan Mental & 154,60 & Setuju \\
3 & Kelelahan Emosional & 149,25 & Setuju \\
4 & Penghargaan Diri Rendah & 154,33 & Setuju \\
& Total & $\mathbf{6 0 5 . 1 8}$ & \\
& Rata-rata & $\mathbf{1 5 1 . 2 9 5}$ & Setuju \\
\hline
\end{tabular}

Sumber: data olahan

Berdasarkan tabel hasil rekap diatas dapat diketahui bahwa rata-rata skor jawaban indikator kelelahan fisik (147), kelelahan mental $(154,6)$, kelelahan emosional $(149,25)$, dan penghargaan diri yang rendah $(154,33)$. Secara keseluruhan rata-rata responden menilai bahwa tanggapan responden terhadap indikator kejenuhan kerja (burnout) pada PT PLN Persero Unit Pengendalian Pembangkit Jambi Unit Layanan Pusat Listrik Payo Selincah berada pada skor 151,295 dan dapat dikategorikan setuju karena berada pada rentang skala 137 - 168. Hal ini membuktikan bahwa karyawan bagian operator di PT PLN Persero Unit Pengendalian Pembangkit Jambi Unit Layanan Pusat Listrik Payo Selincah mengalami kejenuhan kerja. Kondisi ini sesuai dengan Maslach dan Leither (dalam Rizka, 2013) bahwa burnout merupakan reaksi negatif yang terjadi di lingkungan kerja ketika individu mengalami stress yang berkepanjangan. Dengan demikian hipotesis kejenuhan kerja pada PT PLN Persero Sektor Pengendalian Pembangkit Jambi Pusat Listrik Payo Selincah tinggi diterima. 


\section{Analisis Deskrptif terhadap Indikator Kinerja}

Tabel 4

Analisis Deskriptif Terhadap Indikator Kinerja

\begin{tabular}{llll}
\hline No Urut & Indikator & Skor & Keterangan \\
\hline 1 & Kualitas & 157,25 & Setuju \\
2 & Kuantitas & 163,67 & Setuju \\
3 & Ketepatan Waktu & 160,5 & Setuju \\
4 & Efektivitas Biaya & 162 & Setuju \\
5 & Kebutuhan Supervisi & 165,4 & Setuju \\
6 & Dampak Interpersonal & 165 & Setuju \\
& Total & $\mathbf{9 7 3 , 8 2}$ & Setuju \\
\hline
\end{tabular}

Sumber: data olahan

Berdasarkan tabel diatas dapat diketahui bahwa rata-rata skor jawaban indikator kualitas $(157,25)$, kuantitas $(163,67)$, ketepatan waktu $(160,5)$, efektivitas biaya (162), kebutuhan untuk supervisi $(165,4)$, serta dampak interpersonal (165). Secara keseluruhan rata-rata responden menilai bahwa tanggapan responden terhadap indikator kinerja karyawan bagian operator di PT PLN Persero Unit Pengendalian Pembangkit Jambi Unit Layanan Payo Selincah berada pada skor 162,30 dan dapat dikategorikan setuju / baik karena berada pada rentang skala 137-168. Dengan demikian hipotesis kinerja karyawan bagian operator di PT. PLN Persero Unit Pengendalian Pembangkit Jambi Unit Layanan Payo Selincah tinggi diterima. Dengan demikian indikator yang masih dibawah rata-rata adalah indikator kuantitas $(157,25)$. Kenyataan ini menunjukkan bahwa kuantitas kerja masih harus ditingkatkan, menurut Kaswan (2012:187) yang dimaksud dengan kuantitas adalah jumlah yang dihasilkan, dinyatakan dalam nilai, jumlah unit atau jumlah siklus kegiatan yang telah diselesaikan.

\section{Regresi Linier Sederhana}

Untuk melihat mana pengaruh kejenuhan kerja (burnout)terhadap kinerja karyawan bagian operator pada PT PLN Persero Unit Pelaksana Pengendalian Pembangkit Jambi Unit Layanan Pusat Listrik Payo Selincah digunakan rumus regresi linier sederhana yang diolah menggunakan alat bantu program SPSS 21.Hasil perhitungan dengan menggunakan model regresi linier sederhana adalah sebagai berikut :

Tabel 5

Persamaan Regresi Linier Sederhana

\begin{tabular}{|c|c|c|c|c|c|c|}
\hline & \multirow{2}{*}{ Model } & \multicolumn{2}{|c|}{ Unstandardized Coefficients } & \multirow{2}{*}{$\frac{\text { Standardized Coefficients }}{\text { Beta }}$} & \multirow{2}{*}{$\mathrm{t}$} & \multirow{2}{*}{ Sig. } \\
\hline & & $\mathrm{B}$ & Std. Error & & & \\
\hline \multirow{2}{*}{1} & (Constant) & 36.545 & 6.196 & & 5.898 & .000 \\
\hline & BURNOUT & .546 & .137 & .542 & 3.974 & .000 \\
\hline
\end{tabular}

Sumber: data olahan

Berdasaran tabel diatas, diperoleh persamaan regresi linier sederhana dalam penelitisan ini adalah sebagai berikut :

$\mathrm{Y}=36,545+0,546 \mathrm{X}$

Persamaan regresi diatas terdapat nilai $\beta 0$ sebesar 36,545 . Hal ini membuktikan bahwa jika Variabel $X$ (Burnout) bernilai 0, maka Variabel Y (Kinerja) adalah sebesar 0,546. Dengan persamaan diatas, terdapat nilai koefisien regresi variabel bebas $X$ adalah positif yaitu sebesar 0,546. Jika terjadi perubahan pada variabel kejenuhan kerja (burnout), maka akan menyebabkan perubahan secara searah pada variabel kinerja. Dalam penelitian ini maka dapat dianalisis yaitu setiap perubahan peningkatan $1 \%$ dari nilai variabel kejenuhan kerja (burnout), maka nilai variabel kinerja bertambah sebesar 0,546 sehingga bernilai positif dan pengaruh Burnoutterhadap Kinerja adalah positif. 


\section{Korelasi}

Menurut Kurniawan (2009:26) korelasi adalah hubungan atau keeratan antara 2 variabel, dimana terdiri dari 1 variabel independen (bebas) dan 1 variabel dependen (terikat) dan juga mengetahui arah hubungan. Adapun hasil dari korelasi adalah sebagai berikut :

Tabel 6

Correlations

\begin{tabular}{|ll|r|r|}
\hline & & KINERJA & BURNOUT \\
\hline Pearson Correlation & KINERJA & 1.000 & .542 \\
Sig. (1-tailed) & BURNOUT & .542 & 1.000 \\
& KINERJA &. & .000 \\
$\mathrm{~N}$ & BURNOUT & .000 & 40 \\
& KINERJA & 40 & 40 \\
\hline
\end{tabular}

Sumber: data olahan

Hasil perhitungan menggunakan SPSS 21 pada tabel 4diatas dapat disimpulkan bahwa dari terjadi korelasi dimana nilai Pearson Correlation nya yaitu sebesar 0,542 atau $54,2 \%$ yang bilamana nilainya lebih besar daripada $\mathbf{r}_{\text {tabel }}$ yaitu sebesar 0,3120 .

Tabel 6

Determinasi

\begin{tabular}{|l|l|l|l|l|}
\hline Model & R & R Square & Adjusted R Square & Std. Error of the Estimate \\
\hline 1 & $.542^{\mathrm{a}}$ & .294 & .275 & 8.473 \\
\hline
\end{tabular}

Sumber: data olahan

Tabel diatas terjadi korelasi antara variabel kejenuhan kerja (burnout) dengan kinerja dengan skor nilai $\mathrm{R}$ adalah 54,2 \% atau 0,542. Dapat disimpulkan bahwa nilai $\mathrm{R}^{2}$ yaitu sebesar 0,294 atau senilai $29,4 \%$. Hal ini membuktikan bahwa kejenuhan kerja (burnout) mempengaruhi kinerja karyawan bagian operator sebesar 29,4 \%, sedangkan 70,6 \% dipengaruhi oleh variabel - variabel lain yang tidak diteliti dalam penelitian ini.

\section{Uji $t$}

Uji t pada dasarnya menunjukkan seberapa jauh pengaruh satu variabel penjelas secara individual dalam menerangkan variasi variabel terikat.Uji t dilakukan untuk melihat adanya pengaruh dari variabel independen terhadap variabel dependen, uji ini dilakukan dengan cara membandingkan antara $t_{\text {hitung }}$ dengan $t_{\text {tabel }}$, apabila $t_{\text {hitung }}>t_{\text {tabelmaka }} \mathrm{H}_{0}$ ditolak $\mathrm{H}_{1}$ diterima, atau apabila $t_{\text {hitung }}<t_{\text {tabel }}$ maka $\mathrm{H}_{0}$ diterima dan $\mathrm{H}_{1}$ ditolak. Hasil uji t dapat dilihat pada tabel 3 yaitu tabel hasil uji analisis regresi linier sederhana yang ditampilkan pada halaman sebelumnmya. Dari tabel tersebut dapat ditarik kesimpulan bahwa thitung variabel Burnout sebesar 3,974 dengan nilai signifikansi 0,00< 0,05 dimana lebih besar dibandingkan $t_{\text {tabel }} 2,02439$. Jadi dapat ditarik kesimpulan bahwa $\mathrm{H}_{0}$ ditolak dan $\mathrm{H}_{1}$ diterima. Ini berarti Kejenuhan kerja (Burnout)berpengaruh terhadap kinerja karyawan bagian operator pada PT PLN Persero Unit Pengendalian Pembangkit Jambi Unit Layanan Pusat Listrik Payo Selincah.

\section{SIMPULAN} berikut :

Berdasarkan pembahasan pada bab-bab sebelumnya maka dapat ditarik beberapa kesimpulan sebagai

1. Tingkat kejenuhan kerja karyawan bagian operator di PT PLN Persero Unit Pengendalian Pembangkit Jambi Unit Layanan Pusat Listrik Payo Selincah tinggi.Kinerja karyawan bagian operator di PT PLN Persero Unit Pengendalian Pembangkit Jambi Unit Layanan Pusat Listrik Payo Selincah sudah tinggi.

2. Terdapat pengaruh yang signifikan antara kejenuhan kerja (burnout) dengan kinerja karyawan bagian operator di PT PLN Persero Unit Pengendalian Pembangkit Jambi Unit Layanan Pusat Listrik Payo 
Selincah hal ini dapat dibuktikan dengan nilai $\mathrm{t}_{\text {hitung }} 3,974>\mathrm{t}_{\text {tabel }} 2,02439$ dengan nilai signifikansi $0,00<$ 0,05 .

\section{DAFTAR PUSTAKA}

Azwar S (2013), Metode Penelitian, Yogyakarta: Pustaka Pelajar.

Chernis Cary (1980), Staff Burnout-Job Stress in the Human Services, London:Sage Publication, Beverly Hills.

Hakanen J.J, Koivumaki J (2014), Engaged or Exhausted-How Does It Affect Dentist's Clinical Productivity, Journal Burnout Research Vol 1 (12-18).

Manulang (2002), Manajemen Sumber Daya Manusia Edisi Kesebelas, Jakarta.

Maslach Cicilia (1982), Understanding Burnout: Definitional Issues in Analyinga Complex Phenomenon,London: Sage Publications, Beverly Hills.

Maslach Cicilia (1982), Job Stress and Burnout,London: Sage Publications, Beverly Hills.

Maslach Cicilia, Schaufeli WB, Leiter MP (2001), Job Burnout, Annual Reviews. Vol. 52 (397-422), London: Sage Publications, Beverly Hills.

Muslihudin (2011), Kejenuhan Kerja, http://www.lpmpjabar.go.id

Pines Ayala, Aronson Elliot (1989), Career Burnout: Causes and Cures, NewYork: The Free Press, ADivision of Macmillan,Inc.

Sihotang I.N (2004), Burnout pada karyawan ditinjau dari persepsi terhadap Lingkungan kerja psikologis dan jenis kelamin, Palembang: Jurnal PSYCHE No 1, Hal 13-14.

Sugiyono (2012), Metode Penelitian Kuantitatif Kualitatif \& RND, Bandung:Alfabeta.

Suharti Ningsih (2017), The Effect of Burnout, Workload, and Work Conflict Toward Nurses Work Motivation on DR. RM. Pratomo Bagan Siapiapi District Rokan Hilir Hospital, Journal Faculty of Economics Riau Univesity,Indonesia.

Wibisono (2006), Manajemen Kinerja, Jakarta: Erlangga. 